\title{
STUDY OF ANTIHYPERGLYCAEMIC ACTIVITY IN STREPTOZOTOCIN INDUCED DIABETIC MICE AND ANTIOXIDANT ACTIVITIES OF MEDICINAL PLANT EXTRACTS
}

\author{
Nguyen Thi Xuan Thu ${ }^{1, *}$, Dang Duc Long ${ }^{2}$, Thanh Thi Thu Thuy ${ }^{3}$ \\ ${ }^{1}$ University of Science and Technology, The University of Danang, Vietnam \\ ${ }^{2}$ VN-UK Institute for Research and Executive Education, The University of Danang, Vietnam \\ ${ }^{3}$ Institute of Chemistry, VAST, Vietnam
}

Received 24 April 2019, accepted 25 June 2019

\begin{abstract}
Some extracts of medicinal plants have been proven to be beneficial in treating a number of diseases for centuries such as treating diabetes, antioxidant, anti-inflammatory, antibacterial, etc. This study aimed to evaluate the effect of extracts from several herbal plants, such as Gymnema sylvestre, Stevia rebaudiana, Cinnamomum cassia, Zea may, Ocimum basilicumon on blood glucose level in streptozotocin (STZ) induced diabetic mice and to offer scientific proofs for the identified antihyperglycemic effect by investigating on mechanisms of the most effective extract. The results proved that diabetic mice treated with $70 \%$ ethanol extracts of Gymnema sylvestre leaves and Stevia rebaudiana leaves showed significant reduction of the blood glucose levels at a dose of $500 \mathrm{mg} / \mathrm{kg}$ body weight when compared to control $(P<0.05)$. Antihyperglycemic activity of Gymnema sylvestre $(57.68 \%)$ and Stevia rebaudiana extracts $(54.93 \%)$ was significantly higher than those of other extracts. The inhibition of $\alpha$-amylase and $\alpha$-glucosidase activity of Gymnema sylvestreand, Stevia rebaudiana extracts were carried out in vitro. The results demonstrated that these Gymnema sylvestre and Stevia rebaudiana extracts were able to strongly inhibit the activity of $\alpha$-glucosidase and $\alpha$-amylase, with the $\mathrm{IC}_{50}$ values lower than the recently published values around the world about 2-5 times. Using 1,1-diphenyl-2picrylhydrazyl (DPPH) assay showed that Gymnema sylvestre and Stevia rebaudiana extracts exhibited relatively low antioxidant activity with the concentration of a sample required for $50 \%$ scavenging of the DPPH free radical of $115.88 \pm 1.16 \mu \mathrm{g} / \mathrm{mL}$ and $160.27 \pm 2.01 \mu \mathrm{g} / \mathrm{mL}$ compared to vitamin $\mathrm{C}(49.16 \pm 1.26 \mu \mathrm{g} / \mathrm{mL})$.
\end{abstract}

Keywords: DPPH, Diabetes, Antihyperglycemic activity, $\alpha$-Glucosidase inhibitor, $\alpha$-Amylase inhibitor.

Citation: Nguyen Thi Xuan Thu, Dang Duc Long, Thanh Thi Thu Thuy, 2019. Study of antihyperglycaemic activity in streptozotocin induced diabetic mice and antioxidant activities of medicinal plant extracts. Tap chi Sinh hoc, 41(2): 119-128. https://doi.org/10.15625/0866-7160/v41n2.13783.

*Corresponding author email: nguyenthixuanthu85@gmail.com

(O2019 Vietnam Academy of Science and Technology (VAST) 


\title{
NGHIÊN CÚU TÁC DỤNG HẠ ĐƯờnG HUYÊT VÀ CHỐNG OXY HÓA CỦA MộT SỐ CAO CHIẾT THỰC VẬT
}

\author{
Nguyễn Thị Xuân Thu ${ }^{1, *}$, Đặng Đức Long², Thành Thị Thu Thuỷ ${ }^{3}$ \\ ${ }^{1}$ Trường Đại học Bách khoa, Đại học Đà Nẵng, Việt Nam \\ ${ }^{2}$ Viện Nghiên cứu và Đào tạo Việt - Anh, Đại học Đà Nẵng, Việt Nam \\ ${ }^{3}$ Viện Hoá học, Viện Hàn lâm Khoa học và Công nghệ Việt Nam, Việt Nam
}

Ngày nhận bài 24-4-2019, ngày chấp nhận 25-6-2019

\section{TÓM TÁT}

Một số chiết xuất của cây thuốc đã được chứng minh tiềm năng có lợi trong điều trị một số bệnh trong nhiều thế kỷ như điều trị bệnh đái tháo đường (ĐTĐ), khả năng chống oxy hóa, kháng viêm, kháng khuẩn,... Nghiên cứu này nhằm đánh giá tác dụng hạ đường huyết của dịch chiết cồn $70^{\circ}$ của lá dây thìa canh, lá cỏ ngọt, vỏ quế, râu bắp và lá húng quế trên chuột ĐTĐ gây ra bởi streptozocin. Kết quả chứng minh rằng cao lá dây thìa canh và lá cỏ ngọt có khả năng hạ đường huyết đáng kể ở liều $500 \mathrm{mg} / \mathrm{kg}$ so với nhóm chuột đối chứng $(P<0,05)$. Trong đó, chuột uống cao lá dây thìa canh và cỏ ngọt đường huyết tại thời điểm ngày thứ 21 giảm $57,68 \%$ và $54,93 \%$ so với thời điểm 0 giờ. Khả năng ức chế hoạt động của enzyme $\alpha$-amylase và $\alpha$ glucosidase của cao cồn lá dây thìa canh và cỏ ngọt cũng được khảo sát in vitro. Kết quả cho thấy cao chiết cồn của dây thìa canh và cỏ ngọt Việt Nam đều có khả năng ức chế mạnh hoạt động của enzyme $\alpha$-glucosidase và enzyme $\alpha$-amylase, với các giá trị $\mathrm{IC}_{50}$ thấp hơn các giá trị công bố gần đây trên thế giới khoảng $2-5$ lần. Thêm vào đó, kêt quả đo tính chống oxy hoá với 1,1-diphenyl2-picrylhydrazyl (DPPH) cho thấy cao chiết lá dây thìa canh và lá cỏ ngọt thể hiện hoạt tính chống oxy hóa tương đối thấp với nồng độ mẫu cần thiết để quét $50 \%$ gốc tự do DPPH là 115,88 $\pm 1,16 \mu \mathrm{g} / \mathrm{mL}$ và $160,27 \pm 2,01 \mu \mathrm{g} / \mathrm{mL}$ so với vitamin $\mathrm{C}(49,16 \pm 1,26 \mu \mathrm{g} / \mathrm{mL})$.

Từ khóa: DPPH, Đái tháo đường, Hạ đường huyết, $\alpha$-Glucosidase, và $\alpha$-Amylase.

*Địa chỉ liên hệ email: nguyenthixuanthu85@gmail.com

\section{MỞ ĐÀ̀U}

Đái tháo đường (ĐTĐ) là một nhóm các rối loạn chuyển hóa được đặc trưng bởi nồng độ glucose trong máu tăng cao do hậu quả của sự thiếu hụt hoặc giảm hoạt động của insulin (Baynest et al., 2015). Tăng đường huyết trong thời gian dài có liên quan đến các biến chứng vi mạch dẫn đến các bệnh tim mạch, đột quy, mù và bệnh thận (Asmat et al., 2016). Một phương pháp điều trị thực tế để kiểm soát bệnh tiểu đường là kiểm soát tăng đường huyết sau ăn. Điểu này có thể đạt được bằng cách ức chế các enzyme thủy phân carbohydrate như $\alpha$-amylase và $\alpha$-glucosidase có trong đường tiêu hóa. Người ta biết rằng trong tình trạng bệnh đái tháo đường, $\alpha$ glucosidase và $\alpha$-amylase có thể gây bất lợi, do khiếm khuyết sinh hóa khiến nồng độ glucose trong máu tăng cao (Baskaran et al., 1990). Việc ức chế $\alpha$-glucosidase và $\alpha$ amylase có thể làm giảm đáng kể sự gia tăng đường huyết sau ăn do chỉ có thể hấp thụ monosacarit qua niêm mạc ruột, do đó làm giảm nhu cầu insulin và do đó đóng vai trò quan trọng trong việc kiểm soát mức đường huyết ở bệnh nhân tiểu đường (El-Manawaty et al., 2015). Thuốc ức chế $\alpha$-glucosidase, acarbose, cải thiện độ nhạy cảm với insulin và 
giảm đường huyết sau ăn. Tuy nhiên, tác dụng phụ thường gặp nhất được quan sát bằng liệu pháp acarbose là các triệu chứng tiêu hóa (Ruiz-Ruiz et al., 2015).

Có một số yếu tố khác đóng vai trò lớn trong sinh bệnh học của bệnh ĐTĐ như tăng lipid máu và stress oxy hóa dẫn đến nguy cơ biến chứng cao. Stress oxy hóa dẫn đến sự tạo thành các gốc tự do trong cơ thể và đây chính là nguyên nhân chủ yếu dẫn đến kháng insulin, rối loạn lipid máu, rối loạn chức năng tế bào, giảm dung nạp glucose và cuối cùng dẫn đến bệnh ĐTĐ type 2 (Dhasarathan et al., 2011). Bằng cách bổ sung các chất chống $\mathrm{oxy}$ hóa tự nhiên có trong thực vật sẽ có tác dụng ngăn chặn sự tiến triển của bệnh ĐTĐ do các chất chống oxy hóa này có khả năng làm sạch các gốc tự do có hại cho cơ thể từ sự stress oxy hóa (El-Hashash et al., 2010).

Trong y học hiện đại, tác dụng có lợi của thuốc đối với mức độ đường huyết đã được ghi nhận rõ ràng nhưng các loại thuốc này thường quá đắt hoặc có tác dụng phụ nhât định. Do đó, để điều trị bệnh đái tháo đường, nhiều loại cây thuốc truyền thống đã được ưa chuộng làm nguồn thuốc tự nhiên (Tangvarasittichai, 2015) vì chúng được coi là an toàn, ít độc hơn so với thuốc tổng hợp (Ramesh et al., 2006). Bênh cạnh đó, cây thảo dược thường có hoạt tính chống oxy hóa mạnh do vậy các loại cây này trở nên có nhiều hiệu quả hơn trong phòng chống lại bệnh ĐTĐ. Hơn 400 loài thực vật có hoạt động hạ đường huyết đã được công bố, tuy nhiên, tìm kiếm các loại thuốc trị đái tháo đường mới từ thực vật tự nhiên vẫn luôn hấp dẫn vì chúng có chứa những hợp chất có khả năng thay thể và an toàn trong điều trị tiểu đường. Đã có rất nhiều loại thảo dược được nghiên cứu và chứng minh tác dụng hạ đường huyết như: thổ phục linh, dây thìa canh, trà xanh, khổ qua, quế, giảo cổ lam... Hầu hết các thảo dược đều chứa các thành phần như: Glycosides, alkaloid, terpenoid, flavonoid, carotenoid... có tác dụng tốt trong điều trị hạ đường huyết và chống oxy hoá (Patel et al., 2012). Trong nghiên cứu này, ngoài tác dụng hạ đường huyết của dây thìa canh đã được nghiên cứu trước đó ở Việt Nam, các công trình nghiên cứu về tác dụng hạ đường huyết của các cây cỏ ngọt, húng quế, quế, râu bắp là hầu như rất hiếm ở Việt Nam. Kết quả khả năng kiểm soát đường huyết của các cao chiết được chứng minh trên chuột ĐTĐ cũng như khả năng chống oxy hoá của các cao chiết cũng được nghiên cứu và so sánh với các kết quả được công bố gần đây trên thế giới. Các kết quả thu được từ nghiên cứu này sẽ góp phần khẳng định tác dụng chống ĐTĐ của một số loại thảo dược ở Việt Nam, đặc biệt của lá dây thìa canh và lá cỏ ngọt. Việc sử dựng cao chiết cồn của các loại thảo dược này để thử hoạt tính ức chế $\alpha$-glucosidase và $\alpha$-amylase là một đóng góp mới, góp phần tạo ra các thuốc đặc hiệu hơn để chông bệnh tiểu đường từ nguồn dược liệu Việt Nam.

\section{NGUYÊN LIÊU VÀ PHƯONG PHÁP NGHIÊN CÚU}

\section{Nguyên liệu}

Mẫu thực vật được thu mua tại một cơ sở thuốc bắc ở thành phố Đà Nẵng vào khoảng tháng $8-9$. Mẫu được sấy khô ở $50^{\circ} \mathrm{C}$, xay thành bột làm nguyên liệu.

Hóa chất sử dụng trong thí nghiệm gồm: Ethanol, STZ (streptozotocin) của hãng Sigma. Hóa chất dùng pha đệm đạt độ tinh khiết: Đệm citrate $0,01 \mathrm{M}, \mathrm{pH} 4$. Thuốc điều trị đái tháo đường Pioglite (Ấn độ). Enzyme $\alpha$-glucosidase, $\alpha$ - amlylase, thuốc Acarbose $100 \mathrm{mg}$, DNSA (3,5-dinitrosalicylic acid), p-nitrophenyl- $\alpha$-D-glucopyranoside (pNPG) đều mua từ hãng Sigma, Hpa Kỳ. Tinh bột, Dimethyl sulfoside (DMSO) và một số hóa chất khác mua của các hãng hóa chất Việt Nam.

Đối tượng nghiên cứu: Chuột nhắt trắng đực dòng Swiss, khối lượng từ 18-22 g, đuợc cung cấp bởi cơ sở chăn nuôi Suối Dầu - Viện Vắc xin và Sinh phẩm y tế Nha Trang.

\section{Phương pháp nghiên cứu \\ Chiết xuất các mẫu thục vật}

Bột khô khoảng $500 \mathrm{~g}$ từ năm mẫu thực vật (lá dây thìa canh, lá cỏ ngọt, vỏ quế, lá húng quế, râu bắp) được chiết với cồn $70^{\circ}$. Tiến hành cô quay các dịch chiết thu được cao 
cồn tổng. Các cao chiết này được thử nghiệm cho hoạt động hạ đường huyết trên mô hình chuột đái tháo đường cũng như khảo sát khả năng ức chế enzyme $\alpha$-glucosidase, $\alpha$ amlylase và chống oxy hoá.

\section{Nghiên cúu tác dụng của dịch chiết trên chuột đái tháo đường}

Chuột sau 8 tuần cho ăn thức ăn béo được tiêm dung dịch STZ ở nồng độ $120 \mathrm{mg} / \mathrm{kg}$ khối lượng chuột để gây bệnh ĐTĐ (Sawant et al., 2006). Sau khi chuột ĐTĐ ổn định 10 ngày, khả năng hạ đường huyết của các cao chiêt thực vật được xác định bằng cách cho chuột ĐTĐ uống thuốc điều trị ĐTĐ Pioglite (20 mg/kg khối lượng chuột) hoặc các cao chiết $(500 \mathrm{mg} / \mathrm{kg}$ khối lượng chuột) hoặc không được uống thuốc hay các cao chiết thực vật. Chuột ĐTĐ uống cao chiết trong 21 ngày điều trị. Đường huyết được xác định vào $7-8$ giờ sáng trước khi chuột được cho ăn. Sau khi đo các chỉ tiêu chuột được cho ăn và uống nước bình thường.

\section{Nghiên cứu khả năng ức chế enzyme a- glucosidase}

Khả năng ức chế hoạt động của enzyme $\alpha$ glucosidase bởi các cao chiết thực vật được thực hiện theo phương pháp của Salehi và cộng sự (Salehi et al., 2013) có hiệu chỉnh như sau: Hỗn hợp phản ứng bao gồm $200 \mu \mathrm{l} \alpha$ glucosidase $(0,4 \mathrm{U} / \mathrm{mL}), \quad 1.100 \mu \mathrm{L}$ đệm phosphate $0,1 \mathrm{M}(\mathrm{pH} 6,9)$ và $100 \mu 1$ mẫu hoặc Acarbose ở các nồng độ khác nhau. Dung dịch hỗn hợp được ủ ở $37^{\circ} \mathrm{C}$ trong 15 phút. Sau khi ủ sơ bộ, phản ứng enzyme được bắt đầu bằng cách thêm $200 \mu \mathrm{l}$ dung dịch 5-M-pnitrophenyl- $\alpha$-D-glucopyranoside vào đệm phosphate 0,1 M (pH 6,9). Sau đó, hỗn hợp phản ứng được ủ trong 15 phút nữa ở $37^{\circ} \mathrm{C}$. Phản ứng được kết thúc bằng cách thêm 800 $\mu \mathrm{l}$ dung dịch natri cacbonat $0,2 \mathrm{M}$. Sau đó, hỗn hợp phản ứng được đo mật độ quang ở bước sóng $405 \mathrm{~nm}$. Mỗi thử nghiệm được thực hiện lặp lại ba lần. Nồng độ của dịch chiết cần thiết để ức chế $50 \%$ hoạt tính $\alpha$-glucosidase trong điều kiện khảo nghiệm được xác định là giá trị $\mathrm{IC}_{50}$.

\section{Nghiên cứu khả năng ức chế enzyme a- amylase}

Phản ứng ức chế sự thủy phân tinh bột của enzyme $\alpha$-amylase bởi các cao chiết được thực hiện theo phương pháp của Manaharan và cộng sự (Manaharan et al., 2012) có hiệu chỉnh như sau: $500 \mu \mathrm{L}$ hỗn hợp phản ứng trong $0,02 \mathrm{M}$ dung dịch đệm natri phosphate pH 6,9, bao gồm $1 \mathrm{mg} / \mathrm{mL}$ tinh bột, cao chiết ở các nồng độ khác nhau và enzyme $\alpha$ amylase nồng độ $2,5 \mathrm{U} / \mathrm{mL}$. Hỗn hợp phản ứng được ủ 10 phút ở $37^{\circ} \mathrm{C}$. Cuối cùng thêm $500 \mu \mathrm{L}$ thuốc thử DNSA và dung dịch được ủ trong bể nước $95^{\circ} \mathrm{C}$ trong 10 phút. Hồn hợp phản ứng được đo bằng máy đo quang phồ ở bước sóng $540 \mathrm{~nm}$. Tất cả các phép đo đều được thực hiện trong ba lần. Mẫu đối chứng dương được thực hiện bằng thuốc Acarbose.

\section{Xác định khả năng kháng oxy hóa}

Hoạt động chống oxy hoá của các cao chiết từ các mẫu thực vật khác nhau được thực hiện theo quy trình của Shirwaikar và cộng sự (Shirwaikar et al., 2006) có hiệu chỉnh như sau: cao chiết các mẫu thực vật được pha thành các nồng độ là $400 ; 200 ; 100 ; 50 ; 25$ $\mu \mathrm{g} / \mathrm{mL}$ trong ethanol. $150 \mu \mathrm{L}$ cao chiết ở mỗi nồng độ khảo sát được thêm vào $150 \mu \mathrm{L}$ DPPH $500 \mu \mathrm{M}$. Hỗn hợp phản ứng sau khi ủ 30 phút ở $37^{\circ} \mathrm{C}$ trong bóng tối, sau đó đo độ hấp thu quang của các dung dịch ở bước sóng $517 \mathrm{~nm}$. Phần trăm quét gốc tự do (Scavenging effect) DPPH của mẫu thử được tính theo công thức sau:

$$
S C \%=\left[\left(A_{\text {trắng }}-A_{\text {mẫu }}\right) / A_{\text {trắng }}\right] \times 100
$$

Trong đó: $A_{\text {trá́ng }}$ : Là độ hấp thu của mẫu trắng; $A_{\text {mẫu }}$ : Là độ hấp thu của hỗn hợp phản ứng có mẫu thử.

Thí nghiệm được lặp lại ba lần, tính kết quả trung bình. Lập đồ thị biểu hiện mối tương quan giữa $S C$ và thể tích mẫu thử đã dùng, từ đó tính được giá trị $S C_{50}$ của mẫu thử.

\section{KẾT QUẢ VÀ THẢO LUẬN}

\section{Khả năng hạ đường huyết của các cao chiết trên mô hình chuột ĐTĐ}

Từ bảng 1 có thể thấy chuột bị bệnh ĐTĐ type 2 ở lô đối chứng chỉ cho uống nước cất 
thì sau 21 ngày nồng độ đường huyết không giảm, thậm chí còn tăng khi so với thời điểm trước khi điều trị. Nhóm chuột ĐTĐ được điều trị bằng thuốc pioglite $(20 \mathrm{mg} / \mathrm{kg})$, nồng độ đường huyết giảm có ý nghĩa thống kê khi so với nhóm đối chứng ở cùng thời điểm (giá trị $P<0,05)$, và sau 21 ngày uống thuốc nông độ đường huyết giảm $62,86 \%$. Còn trong số 5 mẫu cao chiết thực vật khác nhau được thử nghiệm khả năng hạ đường huyết chỉ có mẫu cao dây thìa canh và cao lá cỏ ngọt thể hiện hoạt tính hạ đường huyết tốt nhất: chuột uống cao dây thìa canh đường huyết tại thời điểm ngày thứ 21 giảm $57,68 \%$, chuột uống cao lá cỏ ngọt giảm 54,93\% (giá trị $P<0,005$ ) so với thời điểm 0 giờ. Cụ thể nồng độ đường huyết của nhóm chuột ĐTĐ type 2 cho uống cao chiết dây thìa canh tại thời điểm ngày thứ 21 là $8,59 \pm 0,88 \mathrm{mmol} / \mathrm{L}$, nhóm uống cao chiết cỏ ngọt là $9,10 \pm 1,29 \mathrm{mmol} / \mathrm{L}$.

Bảng 1. Nồng độ đường huyết của chuột ĐTĐ sau khi uống các cao chiết

\begin{tabular}{|l|c|c|c|}
\hline \multicolumn{1}{|c|}{ Thời gian } & 0 giờ $(\mathrm{mmol} / \mathrm{L})$ & 21 ngày $(\mathrm{mmol} / \mathrm{L})$ & $\begin{array}{c}\text { Tỷ lệ tăng }(+), \\
\text { giảm }(-) \%\end{array}$ \\
\hline Mẫu thử & $19,38^{\mathrm{a}} \pm 1,32$ & $25,97^{\mathrm{a}} \pm 1.63$ & $+34,00$ \\
\hline Piớc cất $(10 \mathrm{~mL} / \mathrm{kg})$ & $21,70^{\mathrm{a}} \pm 2,16$ & $8,06^{\mathrm{b}} \pm 0,70$ & $-62,86$ \\
\hline Cao lá dây thìa canh $(500 \mathrm{mg} / \mathrm{kg})$ & $20,30^{\mathrm{a}} \pm 1,55$ & $8,59^{\mathrm{b}} \pm 0,88$ & $-57,68$ \\
\hline Cao lá cỏ ngọt $(500 \mathrm{mg} / \mathrm{kg})$ & $20,19^{\mathrm{a}} \pm 1,82$ & $9,10^{\mathrm{b}} \pm 1,29$ & $-54,93$ \\
\hline Cao vỏ quế $(500 \mathrm{mg} / \mathrm{kg})$ & $21,10^{\mathrm{a}} \pm 1,20$ & $18,91^{\mathrm{c}} \pm 1,66$ & $-10,38$ \\
\hline Cao lá hung quế $(500 \mathrm{mg} / \mathrm{kg})$ & $18,87^{\mathrm{a}} \pm 1,15$ & $25,60^{\mathrm{a}} \pm 1,16$ & $+35,67$ \\
\hline Cao râu bắp $(500 \mathrm{mg} / \mathrm{kg})$ & $20,60^{\mathrm{a}} \pm 1,74$ & $28,80^{\mathrm{a}} \pm 1,18$ & $+39,81$ \\
\hline
\end{tabular}

Ghi chú: Số chuột trong mỗi nghiệm thức 7 ; các chữ cái theo sau trong cùng một hàng khác biệt thì sẽ khác biệt có ý nghĩa thống kê ở mức $P<0,05$ so với lô chứng bệnh ở cùng thời điểm khảo sát.

Các nghiên cứu của các tác giả trong và ngoài nước cũng đã chứng minh dây thìa canh có tác dụng hiệu quả trong hạ đường huyết ở chuột ĐTĐ (Trần Văn Ởn và nnk., 2014; Baskaran et al., 1990). Nghiên cứu tác dụng hạ đường huyết của cỏ ngọt ở Việt Nam còn rất hạn chế, tuy nhiên đã có một số nghiên cứu trên thế giới chứng minh được hoạt tính sinh học cũng như thành phần hoá học của cỏ ngọt. Ahmad và cộng sự đã chỉ ra rằng cỏ ngọt có khả năng làm giảm nồng độ đường huyết $(66,09 \%)$ và glycohemoglobin $(5,32 \%)$ đáng kể, bên cạnh đó, mức insulin và glycogen gan cũng được cải thiện ở chuột ĐTĐ (Ahmad et al., 1990 ).

Khả năng ức chế enzyme $\alpha$ - amylase và $\alpha$ glucosidase của các cao chiết

\section{Sự ức chế enzyme a-amylase}

Khả năng ức chế enzyme $\alpha$-amylase của các cao chiết dây thìa canh và cỏ ngọt được trình bày ở hình 1 .

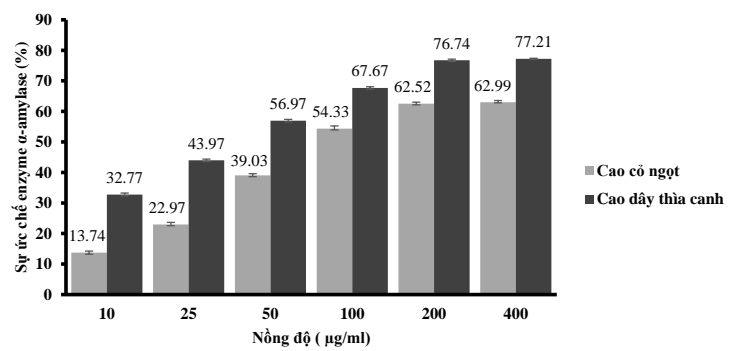

Hình 1. Sự ức chế enzyme $\alpha$-amylase của các cao chiết ở các nồng độ khảo sát

Kết quả trình bày ở hình 1 cho thấy, sự ức chế enzyme $\alpha$-amylase của cao dây thìa canh và cỏ ngọt tỷ lệ tuyến tính với nồng độ cao chiết, khi tăng nồng độ cao chiết thì khả năng ức chế enzyme $\alpha$-amylase càng cao đến khu vực nồng độ của cao chiết đạt $200 \mu \mathrm{g} / \mathrm{mL}$. Điều này được chứng tỏ qua khả năng ức chế của cả cao dây thìa canh và cao cỏ ngọt ở nồng độ $400 \mu \mathrm{g} / \mathrm{mL}$ thể hiện mức độ ức chế tương đương ở nồng độ $200 \mu \mathrm{g} / \mathrm{mL}$ (hình 1). Do đó có thể kết luận đối với cao cỏ ngọt sự 
ức chế enzyme $\alpha$-amylase cao nhất đạt được ở nồng độ $200 \mu \mathrm{g} / \mathrm{mL}$ (mức độ ức chế là 62,52 $\pm 0,50 \%$ ). Tương tự với cao thìa canh, sự ức chế enzyme $\alpha$-amylase cao nhất ở nồng độ cao chiết $200 \mu \mathrm{g} / \mathrm{mL}$ đạt $76,74 \pm 0,38 \%$ và $\mathrm{khu}$ vực nồng độ tăng khả năng ức chế enzyme là từ $10-200 \mu \mathrm{g} / \mathrm{mL}$.

\section{Sự ức chế enzyme a-glucosidase}

Kết quả về sự ức chế enzyme $\alpha$ glucosidase của các cao chiết từ dây thìa canh và cỏ ngọt được trình bày ở hình 2.

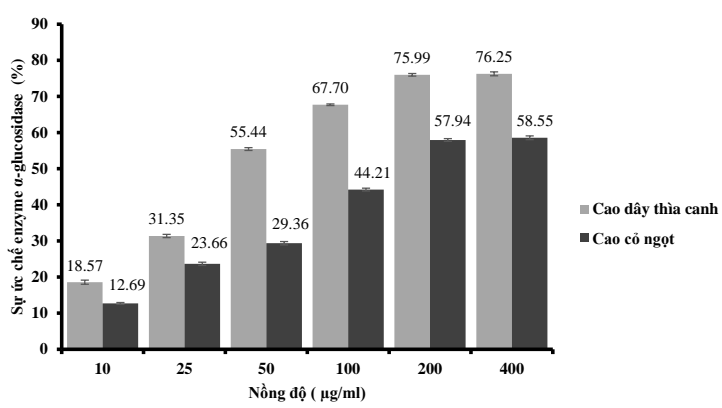

Hình 2. Sự ức chế enzyme $\alpha$-glucosidase của các cao chiết ở các nồng độ khảo sát

Sự ức chế enzyme $\alpha$-glucosidase của các cao chiết được trình bày trong hình 2 . Khả năng ức chế enzyme $\alpha$-glucosidase của cả cao dây thìa canh và cao cỏ ngọt ở nồng độ 400 $\mu \mathrm{g} / \mathrm{mL}$ thể hiện mức độ ức chế tương đương ở nồng độ $200 \mu \mathrm{g} / \mathrm{mL}$ (hình 2). Ở nồng cao chiêt $400 \mu \mathrm{g} / \mathrm{mL}$ và $200 \mu \mathrm{g} / \mathrm{mL}$ cao dây thìa canh thể hiện hoạt tính ức chế cao hơn so với các nồng độ cao còn lại lần lượt là: 76,25 \pm $0,54 \%$ và $75,99 \pm 0,37 \%$. Cao cỏ ngọt có hoạt tính ức chế enzyme $\alpha$-amylase thấp hơn, ở nồng độ $200 \mu \mathrm{g} / \mathrm{mL}$ và $400 \mu \mathrm{g} / \mathrm{mL}$ ức chế $57,94 \pm 0,38 \%$ và $58,55 \pm 0,52 \%$.

Khả năng ức chế của các cao chiết lá dây thìa canh và lá cỏ ngọt với enzyme $\alpha$ amylase và $\alpha$-glucosidase được xác định bằng nồng độ ức chế $50 \%\left(\mathrm{IC}_{50}\right)$ được trình bày trong bảng 2 . Lưu ý rằng khi tính giá trị $\mathrm{IC}_{50}$, chúng tôi chỉ sử dụng khu vực thay đổi tuyến tính của nồng độ ức chế $(10-$ $200 \mu \mathrm{g} / \mathrm{mL}$ ) để đảm bào tính chính xác.

Kết quả về giá trị $\mathrm{IC}_{50}$ đối với enzyme $\alpha$ amylase cho thấy cao dây thìa canh có giá trị
$\mathrm{IC}_{50}$ nhỏ nhất $\left(\mathrm{IC}_{50}=32,97 \pm 0,90 \mu \mathrm{g} / \mathrm{mL}\right)$, tiếp đến là cao cỏ ngọt với giá trị $\mathrm{IC}_{50}=92,70$ $\pm 1,54 \mu \mathrm{g} / \mathrm{mL}$. Các giá trị này thấp hơn so với báo cáo trước đây về chiết xuất quế $\left(\mathrm{IC}_{50}=\right.$ $130,55 \mu \mathrm{g} / \mathrm{mL})$, sa kê $\left(\mathrm{IC}_{50}=118,88 \mu \mathrm{g} / \mathrm{mL}\right)$, trầu không $\left(\mathrm{IC}_{50}=94,63 \mu \mathrm{g} / \mathrm{mlL}\right.$ ) (Nair et al., 2013). Khả năng ức chế hoạt động của enzyme $\alpha$-glucosidase của cao dây thìa canh là tương đối tốt với $\mathrm{IC}_{50}=48,27 \pm 0,84 \mu \mathrm{g} / \mathrm{mL}$, trong khi đó cao cỏ ngọt có giá trị $\mathrm{IC}_{50}$ cao hơn $\left(\mathrm{IC}_{50}=143,67 \pm 2,50 \mu \mathrm{g} / \mathrm{mL}\right)$. Nair và cộng sự đã báo cáo các giá trị $\mathrm{IC}_{50}$ lần lượt là 129,$85 ; 140,01$ và $96,56 \mu \mathrm{g} / \mathrm{mL}$ đối với các chất chiết xuất từ sa kê, quế và trầu không (Nair et al., 2013). Với các giá trị $\mathrm{IC}_{50}$ cao chiết dây thìa canh thấp hơn các cây khác như vậy gợi ý rằng cao chiết dây thìa canh là nguồn dược liệu tốt để ức chế enzyme $\alpha$ amylase và $\alpha$-glucosidase. Đặc biệt hơn nữa, các kết quả của nghiên cứu này sử dụng nguồn nguyên liệu ở Việt Nam có kết quả thấp hơn nhiều các kết quả được công bố gần đây trên thế giới. Đối với dây thìa canh, Ibrahim và cộng sự (Ibrahim et al., 2017) đã kiểm tra với cao chiết methanol và thu được giá trị $\mathrm{IC}_{50}$ cho $\alpha$-amylase là $195,3 \pm 4,40$ $\mu \mathrm{g} / \mathrm{mL}$ và cho $\alpha$-glucosidase là $182,26 \pm 1,05$ $\mu \mathrm{g} / \mathrm{mL}$. Các giá trị này cao hơn giá trị các $\mathrm{IC}_{50}$ cho $\alpha$-amylase và $\alpha$-glucosidase mà chúng tôi thu được với cao chiết cồn của dây thìa canh lần lượt là 5,9 và 3,8 lần. Trong khi đó, kết quả $\mathrm{IC}_{50}$ cho $\alpha$-amylase và $\alpha$-glucosidase của mẫu kiểm chứng (acabose) mà chúng tôi thu được là $203,15 \pm 3,00 \mu \mathrm{g} / \mathrm{mL}$ và $188,76 \pm$ $1,47 \mu \mathrm{g} / \mathrm{mL}$ cũng tương đương với kết quả kiểm chứng cho acabose của Ibrahim và cộng sự (lần lượt là $200,05 \pm 7,16$ và $189,52 \pm 0,46$ $\mu \mathrm{g} / \mathrm{mL})$. Điều này chứng tỏ kết quả sai khác lớn mà chúng tôi thu được ở đây không phải là do sai khác về kỹ thuật đo. Kết quả sai khác này có thể có nguyên nhân từ sự khác nhau về nguồn nguyên liệu, giữa cây dây thìa canh ở Việt Nam và dây thìa canh ở Nigeria trong nghiên cứu của Ibrahim và cộng sự. Một nguyên nhân khác có thể do chúng tồi dùng cao chiết cồn còn nghiên cứu trên dùng cao chiết methanol. Đối với cây cỏ ngọt, RuizRuiz và cộng sự (Ruiz-Ruiz et al., 2015) đã kiểm tra với cao chiết nước nóng và thu được giá trị $\mathrm{IC}_{50}$ cho $\alpha$-amylase là $198,40 \mu \mathrm{g} / \mathrm{mL}$ và 
cho $\alpha$-glucosidase là $596,77 \mu \mathrm{g} / \mathrm{mL}$. Các giá trị này cao hơn giá trị các $\mathrm{IC}_{50}$ cho $\alpha$-amylase và $\alpha$-glucosidase mà chúng tôi thu được với cao chiết cồn của cỏ ngọt lần lượt là 2,1 và 4,2 lần. Các giá trị khác biệt lớn như vậy cũng chỉ có thể do sự khác biệt về nguyên liệu ở Việt Nam và ở Mexico (trong nghiên cứu của
Ruiz-Ruiz và cộng sự), và có thể do sự khác biệt về phương pháp chiết. Tuy vậy, theo các tài liệu về tách chiết hợp chất thiên nhiên, thì giữa việc dùng nước nóng và cồn để chiết thì ít khi có sự khác biệt nhiều về thành phần dịch chiết. Vậy sự khác biệt lớn phần nhiều là do sự khác biệt về nguồn nguyên liệu thiên nhiên.

Bảng 2. Giá trị $\mathrm{IC}_{50}$ của các cao chiết đối với enzyme $\alpha$-amylase và $\alpha$-glucosidase

\begin{tabular}{|l|c|c|}
\hline \multirow{2}{*}{ Chất ức chế $(\mu \mathrm{g} / \mathrm{mL})$} & \multicolumn{2}{|c|}{ Nồng độ ức chế $50 \%\left(\mathrm{IC}_{50}\right)$} \\
\cline { 2 - 3 } & $\alpha$-amylase & $\alpha$-glucosidase \\
\hline Acarbose & $203,15 \pm 3,00$ & $188,76 \pm 1,47$ \\
\hline Cao dây thìa canh & $32,97 \pm 0,90$ & $48,27 \pm 0,84$ \\
\hline Cao cỏ ngọt & $92,70 \pm 1,54$ & $143,67 \pm 2,50$ \\
\hline
\end{tabular}

Từ các kết quả trình bày trên cho thấy cao chiết từ dây thìa canh và cỏ ngọt của Việt Nam có khả năng điều trị bệnh ĐTĐ theo cơ chế ức chế tốt hoạt động của enzyme thủy phân tinh bột là $\alpha$-amylase và $\alpha$-glucosidase. Kết quả của nghiên cứu này bố sung cơ sở khoa học cho y học cổ truyền về khả năng điều trị bệnh ĐTĐ của cao chiết dây thìa canh và cỏ ngọt của Việt Nam.

\section{Hoạt tính kháng oxy hóa bằng phương pháp DPPH}

Nguyên nhân của phần lớn các tình trạng bệnh như xơ vữa động mạch, tăng huyết áp, bệnh Alzheimer's, Parkinson, ung thư, đái tháo đường và các bệnh viêm nhiễm đang được coi chủ yếu là do sự mất cân bằng nội môi giữa quá trình tạo ra các gốc tự do (quá trình oxy hóa) và quá trình sản sinh ra các chất chống oxy hóa (Shirwaikar et al., 2013). Nhiều nghiên cứu đã chứng minh rằng thực vật có khả năng chống oxy hoá rất tốt, chất chống oxy hóa tự nhiên từ thảo dược, đặc biệt là phenolic và flavonoid là an toàn, chúng bảo vệ cơ thể con người bằng việc loại bỏ các gốc tự do (Pal et al., 2011). Xác định khả năng chống oxy hoá bằng phương pháp $\mathrm{DPPH}$ là phương pháp đơn giản, nhanh chóng và ít tốn kém. Trong những năm gần đây phương pháp này cũng được sử dụng để định lượng chất chống oxy hóa trong các hệ thống sinh học phức tạp (Prakash 2000). Các kết quả của hoạt động chống oxy hóa của các cao chiết đã được thể hiện trong phần trăm quét gốc tự do $(\mathrm{SC} \%)$.

Bảng 3. Hoạt tính kháng oxy hóa của các cao chiết

\begin{tabular}{|c|c|c|c|}
\hline \multicolumn{4}{|c|}{ Phần trăm độ hấp thụ DPPH (\%) } \\
\hline $\begin{array}{c}\text { Nồng độ } \\
\mu \mathrm{g} / \mathrm{mL})\end{array}$ & Cẫu cao dây thìa canh & Cao dây cỏ ngọt & Vitamin C \\
\hline 25 & $12,92 \pm 1,80$ & $7,48 \pm 0,68$ & $25,00 \pm 0,54$ \\
\hline 50 & $31,29 \pm 1,36$ & $22,45 \pm 1,18$ & $49,07 \pm 1,09$ \\
\hline 100 & $43,68 \pm 0,58$ & $31,03 \pm 0,99$ & $72,41 \pm 0,99$ \\
\hline 200 & $64,78 \pm 1,67$ & $55,35 \pm 1,66$ & $88,44 \pm 1,36$ \\
\hline 400 & $79,63 \pm 1,07$ & $77,16 \pm 0,62$ & $93,88 \pm 1,17$ \\
\hline $\mathrm{SC}_{50}$ & $115,88 \pm 1,16$ & $160,27 \pm 2,01$ & $49,16 \pm 1,26$ \\
\hline
\end{tabular}


Kết quả thí nghiệm ở bảng 3 cho thấy khả năng làm sạch gốc tự do tỷ lệ thuận với nồng độ của các cao chiết, nồng độ của cao chiết càng cao thì khả năng làm sạch gốc tự do càng lớn và ngược lại. Nhìn chung, khả năng quét gốc tự do DPPH ở nồng độ $25 \mu \mathrm{g} / \mathrm{mL}$ chỉ đạt $12,92 \pm 1,80 \%$ và $7,48 \pm 0,68 \%$ trong cao chiết dây thìa canh và cỏ ngọt. Trong khi đó, ở nồng độ $400 \mu \mathrm{g} / \mathrm{mL}$ độ hấp thụ DPPH của dây thìa canh là $79,63 \pm 1,07 \%$ và thấp hơn là cỏ ngọt 77,16 $\pm 0,62 \%$.

Khả năng làm sạch $50 \%$ các gốc tự do $\mathrm{SC}_{50}$ được tính toán dựa vào đồ thị (hình 3 ) và kết quả được trình bày trong bảng 3 . Trong đó vitamin $\mathrm{C}$ có khả năng làm sạch gốc tự do cao hơn $\left(\mathrm{SC}_{50}=49,16 \pm 1,26 \mu \mathrm{g} / \mathrm{mL}\right)$ so với cao lá dây thìa canh $\left(\mathrm{SC}_{50}=115,88 \pm 1,16 \mu \mathrm{g} / \mathrm{mL}\right)$ và cao lá cỏ ngọt $\left(\mathrm{SC}_{50}=160,27 \pm 2,01 \mu \mathrm{g} / \mathrm{mL}\right)$. Hoạt chất chống oxy hóa của dây thìa canh và cỏ ngọt có thể là đóng vai trò quan trọng về tác dụng có lợi của nó trong điều trị bệnh ĐTÐ (Ahmad et al., 2018).

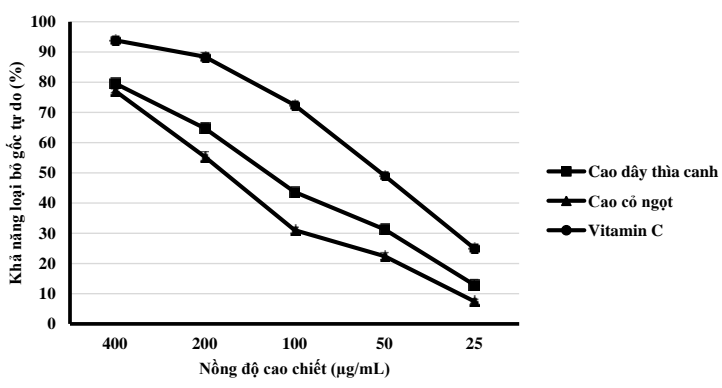

Hình 3. Khả năng làm sạch gốc tự do của các mẫu thử $(\%)$

Cao chiết của lá dây thìa canh thu được từ kỹ thuật tách chiết khác nhau cũng được sử dụng để khảo sát khả năng làm sạch gốc tự do DPPH theo nghiên cứu của Kaskoos và cộng sự (Kaskoos et al., 2015) cũng phù hợp với giá trị $\mathrm{SC}_{50}$ của cao lá trong nghiên cứu này. $\mathrm{SC}_{50}$ của cao lá ngọt trong phản ứng $\mathrm{DPPH}$ theo nghiên cứu của Ruiz-Ruiz và cộng sự (Ruiz-Ruiz et al., 2015) cao hơn $(335,94 \mu \mathrm{g} / \mathrm{mL})$ so với cao lá sử dụng trong thí nghiệm này, nguyên nhân có thể cao chiết sử dụng trong thí nghiệm của Ruiz-Ruiz và cộng sự là cao nước nóng.

\section{KẾT LUẬN}

Trên cơ sở nghiên cứu khả năng hạ đường huyết của các cao chiết thực vật lên chuột ĐTĐ, với kết quả đạt được chúng tôi đưa ra một số kết luận như sau:

Cao chiết lá dây thìa canh và lá cỏ ngọt có tác dụng hạ đường huyết ở chuột ĐTĐ sau 21 ngày uống với liều $500 \mathrm{mg} / \mathrm{kg}$. Trong đó cao chiết dây thìa canh và cỏ ngọt có hoạt tính hạ đường huyết khá cao lần lượt là $57,68 \%$ và $54,93 \%$.

Cao chiết lá dây thìa canh có khả năng ức chế enzyme $\alpha$-amylase và $\alpha$-glucosidase cao với $\mathrm{IC}_{50}$ tương ứng là $32,97 \pm 0,90 \mu \mathrm{g} / \mathrm{mL}$ và $48,27 \pm 0,84 \mu \mathrm{g} / \mathrm{mL}$, trong khi đó cao chiết lá cỏ ngọt có khả năng ức chế hai enzyme này thấp hơn với $\mathrm{IC}_{50}$ lần lượt là $92,70 \pm 1,54$ $\mu \mathrm{g} / \mathrm{mL}$ và $143,67 \pm 2,50 \mu \mathrm{g} / \mathrm{mL}$. Các giá trị này tốt hơn nhiều các giá trị tương ứng đã được công bố trên thế giới gần đây, góp phần khẳng định đặc tính tốt của nguồn nguyên liệu thiên nhiên của Việt Nam để ứng dụng làm dược liệu chống bệnh ĐTĐ.

Cao chiết dây thìa canh và cỏ ngọt thể hiện hoạt tính chống oxy hóa tương đồi thấp với nồng độ mẫu cần thiết để quét $50 \%$ gốc tự do DPPH tương ứng là $115,88 \pm 1,16 \mu \mathrm{g} / \mathrm{mL}$ và $160,27 \pm 2,01 \mu \mathrm{g} / \mathrm{mL}$ so với vitamin $\mathrm{C}$ $(49,16 \pm 1,26 \mu \mathrm{g} / \mathrm{mL})$.

Lời cảm ơn: Công trình được hoàn thành với sự hỗ trợ từ Viện Công nghệ Sinh học - Đại học Huế và Bộ môn Công nghệ Sinh học - Khoa Hóa, trường Đại học Bách khoa Đà Nẵng.

\section{TÀI LIỆU THAM KHẢO}

Ahmad U., Ahmad R. S., 2018. Anti diabetic property of aqueous extract of Stevia rebaudiana Bertoni leaves in Streptozotocin-induced diabetes in albino rats. BMC Complement Altern Med., 18(1): 179.

Asmat U., Abad K., Ismail K., 2016. Diabetes mellitus and oxidative stress-A concise review. Saudi Pharm J., 24(5): 547-553.

$\begin{array}{ccc}\text { Baskaran K., Ahamath } & \text { B. } & \text { K., } \\ \text { Shanmugasundaram } & \text { K. } & \text { P., }\end{array}$ 
Shanmugasundaram E. R. B., 1990. Antidiabetic effect of a leaf extract from Gymnema sylvestre in non-insulinindepent diabetes mellitus patient. $J$. Ethnopharmacol, 30(3): 295-305.

Baynest H. W., 2015. Classification, Pathophysiology, Diagnosis and Management of Diabetes Mellitus. Int $J$ Diabetes Metab, 6(5): 1-9.

Dhasarathan P., Theriappan P., 2011. Evaluation of anti-diabetic activity of Strychonous potatorum in alloxan induced diabetic rats. J. Med. Sci., 2(2): 670-674.

El-Hashash M. M., Abdel-Gawad M. M., ElSayed M. M., Sabry W. A., AbdelHameed el-S. S., Abdel-Lateef el-S., 2010. Antioxidant properties of methanolic extracts of the leaves of seven Egyptian Cassia species. Acta Pharm., 60: 361-367.

El-Manawaty M. A., Gohar L., 2015. In vitro alpha-glucosidase inhibitory activity of egyptian plant extracts as an indication for their antidiabetic activity. Asian J. Pharm. Clin. Res., 11(7): 360.

Ibrahim A., Babandi A., Tijjani A.A., Murtala Y., Yakasai H.M., Shehu D., Babagana K., Umar I. A., 2017. In vitro Antioxidant and Anti-Diabetic Potential of Gymnema Sylvestre Methanol Leaf Extract. European Scien. Jour., 13(36): 218-238.

Kaskoos R. A., Hagop A. B., Faraj A. M., Ahamad J., 2015. Comparative antioxidant activity of Gymnema sylvestre, Enicostemma littoral, Momordica charantia and their composite extract. J. Pharmacogn Phytochem, 4(1): 95-98.

Manaharan T., Appleton D., Cheng H. M., Palanisamy U. D., 2012. Flavonoids isolated from Syzygium aqueum leaf extract as potential antihyperglycaemic agents. Food Chemistry, 132: 1802-1807.

Nair S. S., Kavrekar V., Mishra A., 2013. In vitro studies on alpha amylase and alpha glucosidase inhibitory activities of selected plant extracts. Euro J. Exp Bio., 3(1): $128-132$.
Pal R., Girhepunje K., Shrivastav N., Hussain M. M., Thirumoorthy N., 2011. Antioxidant and free radical scavenging activity of ethanolic extract of Morinda citrifolia. Annals of Biological Research, 2(1): 127-131.

Patel D. K., Prasad S. K., Kumar R., Hemalatha S., 2012. An overview on antidiabetic medicinal plants having insulin mimetic property. Asian Pac J. Trop Biomed, 2(4): 320-330.

Prakash A., Rigelhof F., Miller E., 2000. Antioxidant activity. Analytical progress Medallion Laboratories, 1-4.

Ramesh B., Pugalendi K. V., 2006. Antihyperglycemic effect of Umbelliferone in Streptozotocin diabetic rats. $J$. Med. Plants, 9(4): 562-566.

Ruiz-Ruiz J. C., Moguel-Ordoñez Y. B., Matus-Basto A. J., Segura-Campos M. R., 2015. Antidiabetic and antioxidant activity of Stevia rebaudiana extracts (Var. Morita) and their incorporation into a potential functional bread. J. Food Sci. Technol., 52(12): 7894-7903.

Salehi P., Asghar B., Esmaeili M. A., Dehghan H., Ghazi I., 2013. $\alpha$-Glucosidase and $\alpha$ amylase inhibitory effect and antioxidant activity of ten plant extracts traditionally used in Iran for diabetes. J. Med. Plants Res., 7(6): 257-266.

Sawant S. P., Dnyanmote A. V., Mitra M. S., Chilakapati J., Warbritton A., Latendresse J. R., Mehendale H. M., 2006. Protective effect of type 2 diabetes on acetaminophen-induced hepatotoxicity in male swiss Webster mice. J. Pharmacol. Exp. Ther., 316(2): 507-519.

Shirwaikar A., Rajendran K., Punithaa I. S., 2006. In vivo antionxidant studies on the benzyl tetra isoquinoline alkaloid berberine. Biol. Pharm Bull, 29: 1906-1910.

Tangvarasittichai S., 2015. Oxidative stress, insulin resistance, dyslipidemia and type 2 diabetes mellitus. World J. Diabetes, 6(3): 456-480. 
Trần Văn Ơn, Phùng Thanh Hương, Đỗ Anh Vũ và cộng sự, 2008. Tác dụng hạ đường huyết của dây thìa canh (Gymnema sylvestre (Retz.) R. Br. ex Schult). Tap chí Duoọc hoc, 391: 31-33. 